\title{
Wip1 gene silencing enhances the chemosensitivity of human colon cancer cells
}

\author{
ZHONG-SHENG XIA*, DI WU*, WA ZHONG, XI-JI LU, TAO YU and QI-KUI CHEN \\ Department of Gastroenterology, Guangdong Provincial Key Laboratory of Malignant Tumor Epigenetics and Gene \\ Regulation, Sun Yat-sen Memorial Hospital, Sun Yat-sen University, Guangzhou, Guangdong 510120, P.R. China
}

Received January 7, 2016; Accepted April 13, 2017

DOI: $10.3892 / \mathrm{ol} .2017 .6361$

\begin{abstract}
Colon cancer is one of the most common cancers in the world. Multidrug resistance is one of the main reasons for failure of therapy in patients with advanced colon cancer. In previous studies, multiple methods were investigated to reverse the multidrug resistance of colon cancer cells. However, to date, no clinical method has been identified to be satisfactory. Therefore, successful reversal of drug resistance in colon cancer cells still requires new therapeutic strategies or pharmaceuticals. Wild-type p53-induced phosphatase (Wip1), a member of the $2 \mathrm{C}$ type serine/threonine protein phosphatase family, is closely associated with the p53 gene, which is the most important tumor-suppressor gene. Wip1 was reported to be associated with the chemosensitivity of breast cancer cells. However, the correlation between the expression of Wipl gene and the chemosensitivity of colon cancer cells has not been reported yet. In the present study, Wip1-811 small interfering RNA (siRNA) targeting Wip1 was investigated to reverse the multidrug resistance of colon cancer cells. The siRNA duplexes were transfected into RKO colon cancer cells. The messenger RNA (mRNA) expression of Wip1 was measured by reverse transcription-quantitative polymerase chain reaction. The protein level of Wip1 was detected by western blotting. The cell viability was measured by MTS assay. The cell apoptosis and cell cycle were analyzed by flow cytometry. Intracellular adriamycin cumulative concentration was determined using flow cytometry. Wip1-811 siRNA efficiently inhibited the expression of Wipl at the mRNA and protein levels, and enhanced the sensitivity of RKO colon cancer cells
\end{abstract}

Correspondence to: Dr Zhong-Sheng Xia, Department of Gastroenterology, Guangdong Provincial Key Laboratory of Malignant Tumor Epigenetics and Gene Regulation, Sun Yat-sen Memorial Hospital, Sun Yat-sen University, 107 YanjiangXi Road, Guangzhou, Guangdong 510120, P.R. China

E-mail: xiazhsh@163.com

*Contributed equally

Key words: colon cancer, small interfering RNA, Wip1 gene, chemosensitivity towards chemotherapy, which was accompanied by increased cell apoptosis, following the inhibition of Wipl gene expression. These results indicate that Wip1 gene silencing could enhance the chemosensitivity of colon cancer cells, which may provide a new potential approach for the reversal of multidrug resistance in colon cancer cells.

\section{Introduction}

Colon cancer is one of the most common malignant gastrointestinal tumors. The morbidity and mortality of colon cancer in the world as well as in China are gradually increasing (1). The majority of patients with colon cancer are in advanced stage by the time of diagnosis (2); thus, surgery is rarely a sufficient treatment. Consequently, chemotherapy is markedly important in the treatment of colon cancer. However, chemotherapy's effectiveness is limited because colon cancer cells acquire multiple drug resistance (MDR) (3).

To improve the effect of chemotherapy in the treatment of colon cancer, one of the major challenges is reversing MDR in colon cancer cells. In previous studies, calcium antagonists such as verapamil (4) and small interfering RNA (siRNA) targeting multidrug resistance protein 1 (MDR1) messenger RNA (mRNA) were observed to modulate MDR1/P-glycoprotein (P-gp)-dependent MDR by downregulating the expression of MDR1 mRNA and P-gp (5). However, calcium antagonists may cause heart failure and hypotension (6), and the clinical benefit of siRNA targeting MDR1 mRNA has not been reported thus far. Therefore, successful reversal of drug resistance still requires new therapeutic strategies or pharmaceuticals.

Wild-type p53-induced phosphatase (Wip1) is a member of the $2 \mathrm{C}$ type serine/threonine protein phosphatase family (7). Wip1 is closely associated with the p53 gene and it can dephosphorylate downstream proteins of the p53 gene, thus causing the degradation of $\mathrm{p} 53$ protein and the inhibition of DNA repair and cell apoptosis mediated by p53 (8-10). Thereby, Wip1 promotes tumorigenesis (11). The Wip1 gene has been reported to be overexpressed in a variety of tumors $(12,13)$. Previous studies reported an association between Wip1 and sensitivity towards chemotherapy. For example, self-proliferation of cancer stem cells was inhibited by downregulation of Wip1, which improved the chemosensitivity of breast cancer cells (14). However, the correlation between the expression of 
the Wipl gene and the chemosensitivity of colon cancer cells has not been reported yet.

In the present study, RNA interference (RNAi) was used to observe the inhibition of the Wip1 gene induced by a specific siRNA sequence and to investigate the influence of Wip1 gene silencing on the chemosensitivity of colon cancer cells. Therefore, a new potential method may have been identified to reverse the drug resistance of colon cancer cells.

\section{Materials and methods}

Cell culture. RKO and COLO 320DM human colon adenocarcinoma cell lines were purchased from Shanghai Cell Bank of Chinese Academy of Sciences (Shanghai, China) and were cultured in RPMI-1640 medium (Gibco; Thermo Fisher Scientific, Inc., Waltham, MA, USA) supplemented with $10 \%$ fetal bovine serum (FBS) (Biological Industries Israel Beit-Haemek, Kibbutz Beit-Haemek, Israel), 100 U/ml penicillin and $100 \mu \mathrm{g} / \mathrm{ml}$ streptomycin at $37^{\circ} \mathrm{C}$ in a humidified incubator containing $5 \% \mathrm{CO}_{2}$.

Western blotting. Cells were washed twice with PBS and then lysed with $100 \mu \mathrm{l}$ lysis buffer (91 $\mu \mathrm{l}$ radioimmunoprecipitation assay buffer $+9 \mu 1$ 10X protease cocktail; Beijing Kangwei Century Biotechnology Co., Ltd., Beijing, China) on ice for $30 \mathrm{~min}$. Cell lysates were centrifuged at $14,000 \mathrm{x} \mathrm{g}$ for $20 \mathrm{~min}$ at $4^{\circ} \mathrm{C}$. The total cellular protein content was determined with $\mathrm{BCA}^{\mathrm{TM}}$ Protein Assay kit (Beijing Kangwei Century Biotechnology Co., Ltd, Beijing, China). Subsequently, cellular proteins $(20 \mu \mathrm{g})$ were dissolved in sample loading buffer (Beijing Kangwei Century Biotechnology Co., Ltd.) and subjected to $10 \%$ SDS-PAGE. Proteins were electrotransferred to polyvinylidene fluoride membranes $(200 \mathrm{~mA}$, $90 \mathrm{~min})$. The membranes were rinsed with PBS and blocked with 5\% nonfat milk in PBS for $90 \mathrm{~min}$ at room temperature. The membranes were then incubated with primary polyclonal anti-Wip1 (1:1,000; GeneTex, Inc., Irvine, CA, USA) or monoclonal anti-GAPDH antibodies (cat. no., MB001H; 1:1,000; Bioworld Technology, Inc., St. Louis Park, MN, USA) in 5\% nonfat milk overnight at $4^{\circ} \mathrm{C}$. Following primary antibody incubation, the membranes were rinsed in TBS containing Tween-20 (TBS-T) wash buffer four times (10 min each). The membranes were then incubated with a secondary antibody (cat. no., E030120-02; horseradish peroxidase-conjugated goat anti-rabbit immunoglobulin G; 1:5,000; EarthOx Life Sciences, Millbrae, CA, USA) for $1 \mathrm{~h}$ at room temperature and rinsed in TBS-T wash buffer four times (5 min each). The protein-antibody complexes were visualized by chemiluminescence (ECL Plus Western Blotting Substrate; Thermo Fisher Scientific, Inc.).

Reverse transcription-quantitative polymerase chain reaction $(R T-q P C R)$. Total RNA was isolated from cells using RNAiso Plus (Takara Biotechnology Co., Ltd., Dalian, China) according to the manufacturer's protocol. Single stranded complementary DNA (cDNA) was synthesized from $1 \mu \mathrm{g}$ RNA using cDNA Synthesis kit (Takara Biotechnology Co., Ltd.). The newly synthesized cDNA was amplified by PCR using an iCycler iQ $^{\mathrm{TM}}$ Real-Time PCR Detection System (Bio-Rad Laboratories, Inc., Hercules, CA, USA). The reaction mixture contained $2 \mu \mathrm{l}$ of cDNA template, $0.4 \mu \mathrm{l}$ of $10 \mu \mathrm{M}$ Wipl sense primer (5'-CAGGGAAACTTTACCAATGAA -3'), $0.4 \mu \mathrm{l}$ of $10 \mu \mathrm{M}$ Wipl antisense primer (5'-ACGAAC CAGGGCAGGTATAT-3'), $10 \mu$ l of SYBR Premix Ex Taq ${ }^{\mathrm{TM}}$ (Takara Bio Inc., Otsu, Japan) and $7.2 \mu \mathrm{l}$ of distilled $\mathrm{H}_{2} \mathrm{O}$. The final reaction volume was $20 \mu \mathrm{l}$. Both sense (5'-CCTGGA TACCGCAGCTAGGA-3') and antisense (5'-GCGGCGCAA TACGAATGCCCC-3') 18S ribosomal RNA (rRNA) primers were used as internal controls. The cycling conditions were as follows: $95^{\circ} \mathrm{C}$ for $30 \mathrm{sec}$ to denature the cDNA and primers, followed by 40 cycles at $95^{\circ} \mathrm{C}$ for $5 \mathrm{sec}$ and $60^{\circ} \mathrm{C}$ for $20 \mathrm{sec}$. Dissociation curve analysis (15) was performed according to the following conditions: $95^{\circ} \mathrm{C}$ for $0 \mathrm{sec}, 60^{\circ} \mathrm{C}$ for $15 \mathrm{sec}$ and $95^{\circ} \mathrm{C}$ for $0 \mathrm{sec}$. The amplification products of Wip 1 and $18 \mathrm{~S}$ rRNA were 180 and 112 bp in size, respectively. The relative expression of Wip1 mRNA was calculated by comparing it with the mRNA expression of the negative control, which was set as 1 .

siRNA synthesis and transfection. The siRNA sequences targeting Wip1 (GenBank accession no. NM008493) were designed by Suzhou Jima Gene Co. Ltd. (Suzhou, China). Wip1 siRNA duplexes (Wip1-811 siRNA), positive control (GAPDH) siRNA and negative control siRNA were synthesized by Suzhou Jima Gene Co. Ltd. For Wip1-811 siRNA, the sense strand was 5'-GGGUGGUUCUUGGAAUUC ATT-3' and the antisense strand was 5'-UGAAUUCCAAGA ACCACCCTT-3'. Cells treated with Lipofectamine ${ }^{\mathrm{TM}} 2000$ (Thermo Fisher Scientific, Inc.) and Opti-MEM ${ }^{\circledR}$ I Reduced Serum Medium (Thermo Fisher Scientific, Inc.) were set as the liposome control. The siRNA duplexes were transfected using Lipofectamine ${ }^{\mathrm{TM}} 2000$ according to the protocol recommended by the manufacturer. Serial concentrations of Wip1 siRNA, including 5, 10, 25, 50 and $100 \mathrm{nmol} / \mathrm{l}$, were used to screen the optimal concentration of Wip1 siRNA. A series of transfection times, including 24, 48, 72 and $96 \mathrm{~h}$, were used to screen the optimal transfection time.

MTS assay. Cell viability assays were performed by MTS assay. Cells were seeded at $1 \times 10^{4}$ cells/well in 96-well microtiter plates. After $24 \mathrm{~h}$ of incubation, Wip1-811 siRNA transfection was performed. A series of diluted concentrations of anti-tumor drugs, including 5-fluorouracil (5-FU; Sigma-Aldrich; Merck KGaA, Darmstadt, Germany), oxaliplatin (Sigma-Aldrich; Merck KGaA) and adriamycin (Sigma-Aldrich; Merck KGaA), were added to the cells $24 \mathrm{~h}$ after transfection. Then, the cells were incubated for 3 days at $37^{\circ} \mathrm{C}$ in $5 \% \mathrm{CO}_{2}$. Subsequently, $20 \mu \mathrm{l}$ of MTS solution (Promega Corporation, Madison, WI, USA) was added to the cells and incubated for $3 \mathrm{~h}$ at $37^{\circ} \mathrm{C}$, followed by agitation for $5 \mathrm{~min}$. Optical density (OD) values were read on a Synergy HT Multi-Detection Microplate Reader (Bio-Tek Instruments, Inc., Winooski, VT, USA) at a wavelength of $570 \mathrm{~nm}$. Cell viability was calculated by comparison with the OD value of the control, and the half-maximal inhibitory concentration $\left(\mathrm{IC}_{50}\right)$ of the anti-tumor drug in each group was further calculated.

Analysis of cell apoptosis and cell cycle. RKO colon cancer cells were plated at $5 \times 10^{5}$ cells/well in 12-well plates in RPMI-1640 medium with $10 \%$ FBS. After 24 h of incubation, Wip1-811 
siRNA transfection was performed. 5-FU or oxalipatin were added $24 \mathrm{~h}$ after transfection to a final concentration of $5 \mu \mathrm{mol} / 1$. Then, cells were incubated at $37^{\circ} \mathrm{C}$ and $5 \% \mathrm{CO}_{2}$ for $48 \mathrm{~h}$. Subsequently, the cells were harvested and washed twice with cold PBS, and then divided into two tubes. One tube of cells was used for analysis of cell apoptosis, in which $1 \times 10^{6}$ cells $/ \mathrm{ml}$ of cell suspension was obtained by adding $5 \mu \mathrm{l}$ of Annexin V-FITC (BD Biosciences, San Jose, CA, USA) and $200 \mu \mathrm{l}$ of $1 \mathrm{X}$ binding buffer (BD Biosciences). Propidium iodide $(10 \mu \mathrm{l})$ (Thermo Fisher Scientific, Inc.) was next added and allowed to react in the dark for $30 \mathrm{~min}$. Next, the cell suspension was subjected to analysis of cell apoptosis. The other tube of cells was prepared for analysis of the cell cycle. Briefly, the cells were fixed with $2 \mathrm{ml}$ of $70 \%(\mathrm{v} / \mathrm{v})$ ethanol at $4^{\circ} \mathrm{C}$, and then resuspended by adding $200 \mu \mathrm{l}$ of PBS. The next day, the fixed cells were ready for analysis of the cell cycle. Flow cytometry analysis was performed with a FACSVerse ${ }^{\mathrm{TM}}$ flow cytometer (BD Biosciences). For each sample, 10,000 cells were analyzed.

Intracellular adriamycin accumulation assay. The fluorescence intensity of intracellular adriamycin was determined using flow cytometry according to a standard method (16). Cells were plated at $2 \times 10^{5}$ cells/well in 6 -well plates $24 \mathrm{~h}$ prior to siRNA transient transfection, and then incubated for $48 \mathrm{~h}$. Next, adriamycin (final concentration, $10 \mu \mathrm{mol} / \mathrm{l}$ ) was added to the cells and incubated for $2 \mathrm{~h}$. The cells were then harvested, washed twice with cold PBS and placed in ice-water to block the reaction until analysis. After $30 \mathrm{~min}$, the fluorescence intensity of the cells was determined by FACSVerse ${ }^{\mathrm{TM}}$ flow cytometry at an excitation wavelength of $488 \mathrm{~nm}$ and a detection wavelength of $575 \mathrm{~nm}$. COLO 320DM colon cancer cells transfected with MDR1 siRNA (\#4123; Thermo Fisher Scientific, Inc.) were used as the positive control and compared with COLO 320DM colon cancer cells (5).

Statistical analysis. All measurement data were present as mean \pm standard deviation (SD). The differences among multiple mean values were evaluated using one-way analysis of variance (ANOVA) and post-hoc Tukey's test. The differences between two mean values were estimated using independent-samples t-test. All of the statistical analyses were processed with the statistical analysis software SPSS, version 19.0 (IBM Corp, Armonk, NY, USA).

\section{Results}

Optimal inhibitory concentration of Wipl siRNA on the mRNA and protein expression of Wipl in RKO colon cancer cells. In order to investigate the inhibitory effect of siRNA on the mRNA and protein expression of Wip1, RKO colon cancer cells were seeded in a 24-well plate. Serial concentrations of Wip1-811 siRNA (range, 5-100 nmol/l) were transfected into RKO colon cancer cells. Cells cultured in medium without liposomes or siRNA treatment were used as controls. The liposome control was treated only with Lipofectamine ${ }^{\circledR}$ 2000. Negative controls were treated with a control siRNA containing no homology to any human gene. Cells of each group were harvested 24 or $48 \mathrm{~h}$ after transfection. RT-qPCR detected the expression of Wip1 mRNA. Western blotting examined the expression of Wip1 protein. Fig. 1A shows the influence of different concentrations of Wip1-811 siRNA on the relative mRNA expression of Wip1 in RKO colon cancer cells $24 \mathrm{~h}$ after siRNA transfection. No significant differences were observed in Wip1 mRNA levels between the control, liposome control and negative control groups $24 \mathrm{~h}$ after transfection. However, there was a significant difference between the Wip1 siRNA groups and the negative control group $(\mathrm{P}<0.05$; Fig. 1A). This indicated that different concentrations of Wip1 siRNA decreased Wip1 mRNA expression $24 \mathrm{~h}$ after transfection. The expression of Wip1 mRNA was the lowest when the concentration of Wip1-811 siRNA was $50 \mathrm{nmol} / 1$. The results from RT-qPCR at $48 \mathrm{~h}$ post-transfection were similar to those at $24 \mathrm{~h}$ post-transfection (Fig. 1B). No significant differences were observed in Wip1 protein expression between the control, liposome control and negative control groups $24 \mathrm{~h}$ after transfection (Fig. 2A). However, there was a significant difference between the Wipl siRNA groups, except for $5 \mathrm{nmol} / \mathrm{l}$ siRNA, and the negative control group $(\mathrm{P}<0.05)$. This indicated that a Wipl siRNA range of 10-100 nmol/1 inhibits Wip1 protein expression $24 \mathrm{~h}$ after transfection. Wip1 protein expression was the lowest when the concentration of Wip1-811 siRNA was $50 \mathrm{nmol} / 1$ (Fig. 2A). The results from western blot at $48 \mathrm{~h}$ post-transfection were similar to those at $24 \mathrm{~h}$ post-transfection, except for $5 \mathrm{nmol} / 1 \mathrm{siRNA}$ (Fig. 2B). Therefore, the optimal concentration of Wip1-811 siRNA appeared to be $50 \mathrm{nmol} / \mathrm{l}$ based on the results from 24 and $48 \mathrm{~h}$ post-transfection.

Duration of the inhibitory effect of Wipl siRNA on the mRNA and protein expression of Wipl in RKO colon cancer cells. In order to investigate the duration of the inhibition of Wip1 siRNA on the mRNA and protein expression of Wip1 following transient transfection, $50 \mathrm{nmol} / \mathrm{l}$ of Wip1-811 siRNA was transfected into RKO colon cancer cells. Cells were harvested at 24-96 h post-transfection. As shown by RT-qPCR in Fig. 3, the relative expression of Wip1 mRNA in RKO colon cancer cells in the Wipl siRNA groups was significantly lower than that in negative control groups at any time point. In addition, the longer the time post-transfection, the lower the inhibitory effect of Wip1-811 siRNA. The western blot analysis was consistent with the results from RT-qPCR (Fig. 4). According to the above results, the optimal time of transfection of Wip1-811 siRNA was determined to be between 24 and $48 \mathrm{~h}$.

Wipl gene silencing enhances the chemosensitivity of RKO colon cancer cells. Wip1-811 siRNA (50 nmol/1) was transfected into RKO colon cancer cells, and $24 \mathrm{~h}$ after transfection, serial concentrations of 5-FU, oxaliplatin and adriamycin were added to treat RKO colon cancer cells for $48 \mathrm{~h}$. According to the results of MTS assay, the cell viability of RKO colon cancer cells without chemotherapy treatment in the Wip1-811 siRNA group exhibited no significant difference compared with that of the control, liposome control and negative control groups. The cell viability of RKO colon cancer cells in these control groups and in the Wip1-811 siRNA group decreased along with increasing concentrations of the antitumor drugs (data not shown). The $\mathrm{IC}_{50}$ of the Wip1-811 siRNA group following treatment with $5-\mathrm{FU}(25.32 \pm 2.59 \mu \mathrm{mol} / \mathrm{l})$ was 

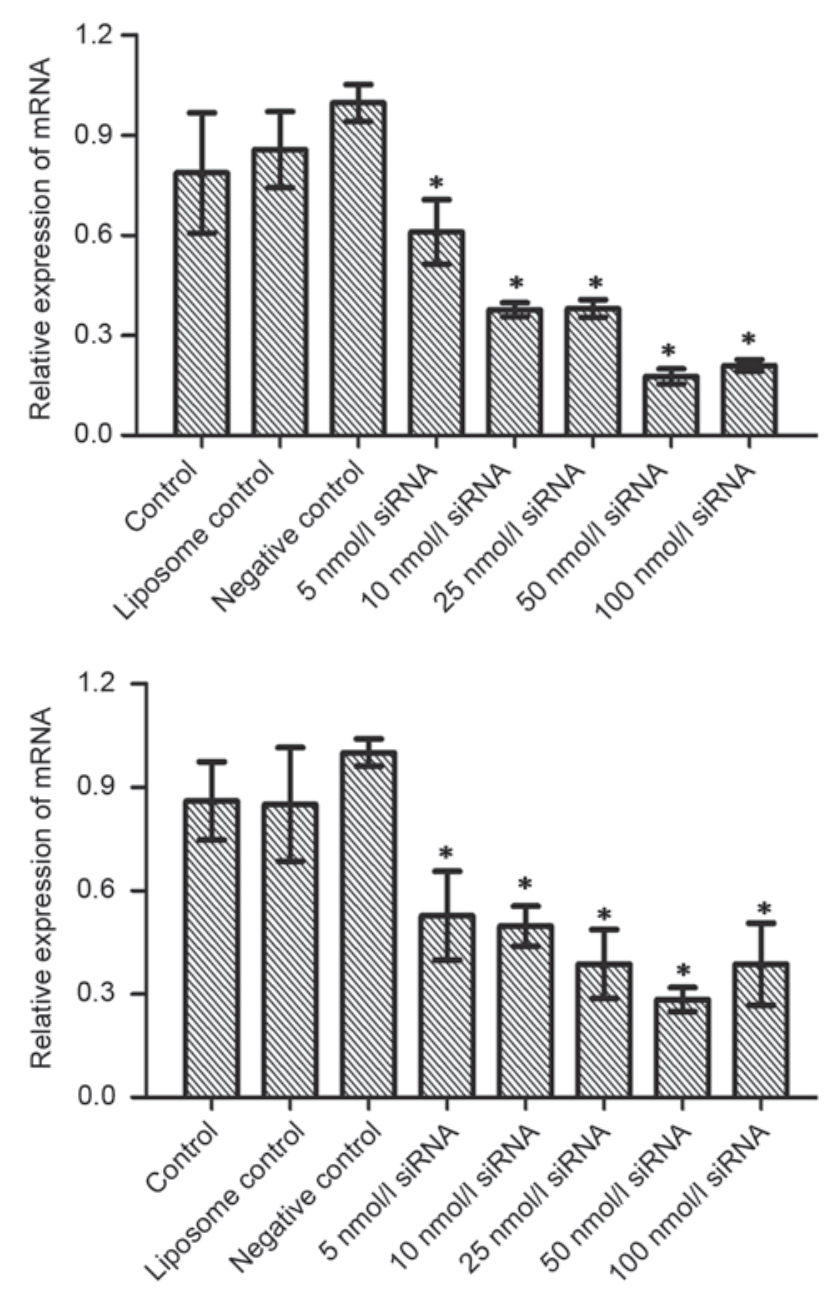

Figure 1. Influence of different concentrations of Wip1-811 siRNA on the relative mRNA expression of Wip1 in RKO colon cancer cells (A) 24 and (B) $48 \mathrm{~h}$ after transfection. " $\mathrm{P}<0.05$ vs. negative control. Wip1, wild-type p53-induced phosphatase; siRNA, small interfering RNA; mRNA, messenger RNA.

significantly decreased when compared with that of the negative control group $(56.88 \pm 6.08 \mu \mathrm{mol} / 1)$. Similarly, the $\mathrm{IC}_{50}$ of the Wip1-811 siRNA group following treatment with oxaliplatin $(18.74 \pm 2.21 \mu \mathrm{mol} / \mathrm{l})$ was significantly lower than that of the negative control group $(43.60 \pm 3.72 \mu \mathrm{mol} / \mathrm{l})$. In addition, the $\mathrm{IC}_{50}$ of the Wip1-811 siRNA group following treatment with adriamycin $(0.88 \pm 0.08 \mu \mathrm{mol} / \mathrm{l})$ was significantly lower than that of the negative control group $(2.13 \pm 0.20 \mu \mathrm{mol} / \mathrm{l})$ (Table I).

The results presented in Table I demonstrate that Wip1-811 siRNA alone was not able to kill RKO colon cancer cells. However, a larger number of RKO colon cancer cells were killed when treated with Wip1-811 siRNA combined with 5-FU, oxaliplatin and adriamycin compared with those in the negative control group.

Downregulation of Wipl gene expression increases cell apoptosis induced by chemotherapeutic drugs. In order to investigate the mechanism of Wipl gene silencing on the enhanced chemosensitivity of RKO colon cancer cells, based on the results of MTS assay, $5 \mu \mathrm{mol} / 1$ of 5-FU and oxaliplatin were applied to treat RKO colon cancer cells for $48 \mathrm{~h}$ after transfection, and cell apoptosis was then detected by flow
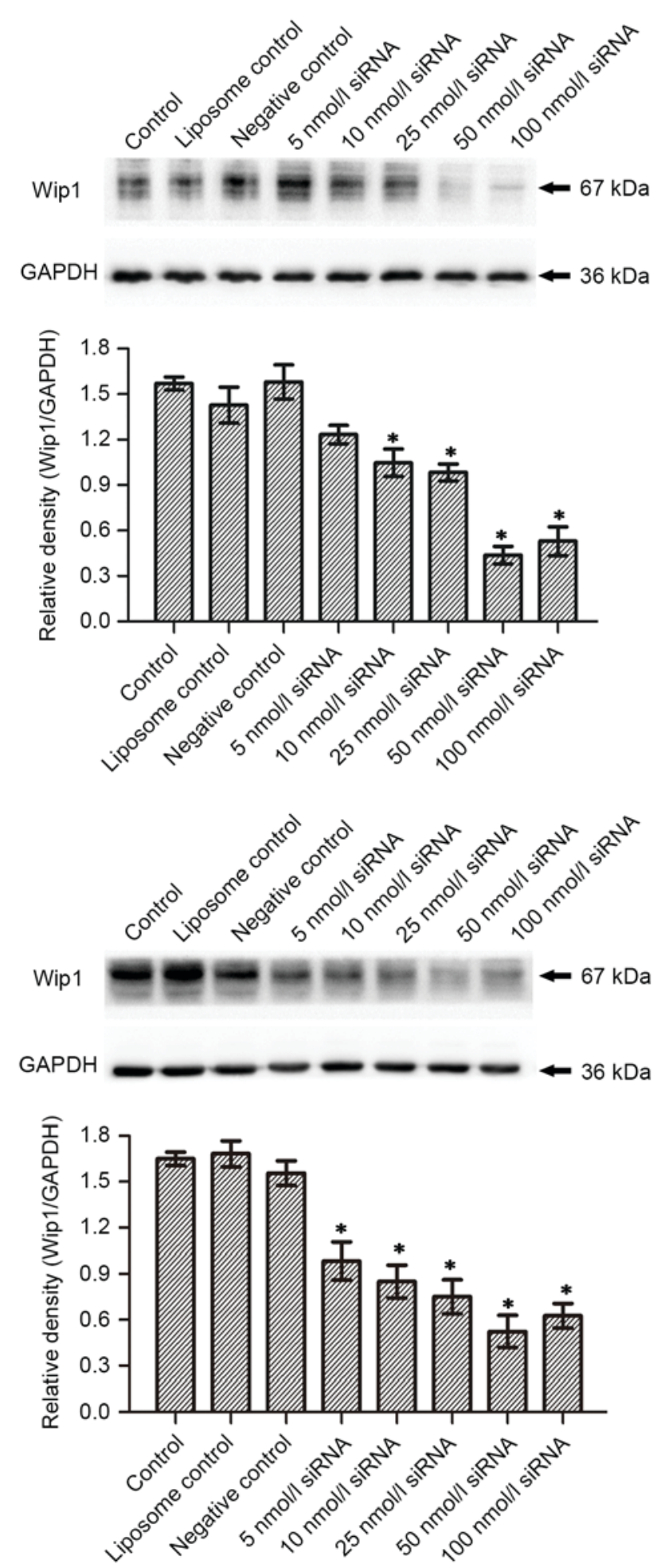

Figure 2. Influence of different concentrations of Wip1-811 siRNA on the protein expression of Wip1 in RKO colon cancer cells (A) 24 and (B) $48 \mathrm{~h}$ after transfection. "P<0.05 vs. negative control. Wip1, wild-type $\mathrm{p} 53$-induced phosphatase; siRNA, small interfering RNA.

cytometry. Figs. 5 and 6 indicate that both 5-FU and oxaliplatin could induce cell apoptosis in RKO colon cancer cells. Wip1-811 siRNA alone could not induce cell apoptosis in RKO colon cancer cells without treatment of chemotherapeutic drug. However, Wip1-811 siRNA could increase the cell apoptosis of RKO colon cancer cells when in combination with antitumor 


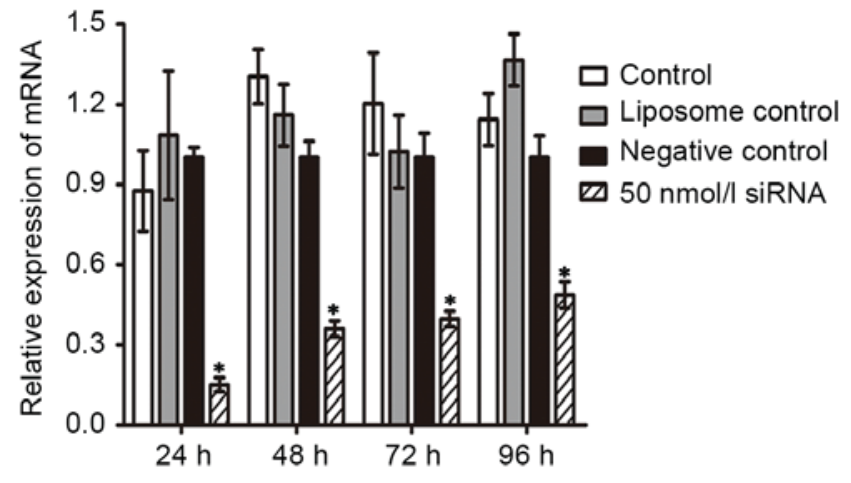

Figure 3. Influence of Wip1-811 siRNA on the relative mRNA expression of Wip1 in RKO colon cancer cells after transfection for $24-96$ h. ${ }^{*} \mathrm{P}<0.05$ vs. negative control at the same time point. Wip1, wild-type p53-induced phosphatase; siRNA, small interfering RNA; mRNA, messenger RNA.

drugs, compared with that of the negative control. The results indicate that the downregulation of Wip1 gene expression could increase the cell apoptosis of RKO colon cancer cells induced by antitumor drugs.

Influence of Wipl gene silencing on the cell cycle of RKO colon cancer cells. As shown in Table II, there was no significant difference in the cell cycle between the siRNA group and the control group $(\mathrm{P}>0.05)$. This result indicates that Wip1-811 siRNA by itself had no influence on the cell cycle of RKO colon cancer cells in the absence of antitumor drugs. 5-FU could induce RKO colon cancer cell arrest in G1 phase. Therefore, 5-FU could increase the percentage of cells in G1 phase and decrease the percentage of cells in $\mathrm{S}$ phase $(\mathrm{P}<0.05)$. Oxaliplatin could induce RKO colon cancer cell arrest in $\mathrm{G} 2 / \mathrm{M}$ phase $(\mathrm{P}<0.05)$. However, the percentage of cells in each cell cycle phase was not changed following Wip1 siRNA transfection in combination with 5 -FU or oxaliplatin treatment compared with that following 5-FU or oxaliplatin treatment alone. This result indicates that Wip1 gene silencing has no significant influence on the cell cycle of RKO colon cancer cells induced by $5-\mathrm{FU}$ or oxaliplatin.

Influence of Wipl gene silencing on intracellular adriamycin accumulation in RKO colon cancer cells. To investigate if Wip1-811 siRNA could increase intracellular antitumor drug accumulation, an intracellular adriamycin accumulation assay was performed using COLO 320DM and RKO colon cancer cells. Table III shows that, when treated with adriamycin, the fluorescence intensity of COLO 320DM colon cancer cells was 196.45 AU. However, the fluorescence intensity increased to $410.63 \mathrm{AU}$ when cells were treated with adriamycin combined with the positive control \#4123 MDR1 siRNA $(\mathrm{P}<0.05)$. As shown in Table III, when RKO colon cancer cells were treated with adriamycin, adriamycin fluorescence could be detected in all groups, including the control, liposome control and negative control groups, as well as in the Wip1-811 siRNA group. However, there was no significant difference in the fluorescence intensity of adriamycin among these groups $(\mathrm{P}>0.05)$. This indicates that Wip1-811 siRNA had no effect on intracellular adriamycin accumulation in RKO colon cancer cells.
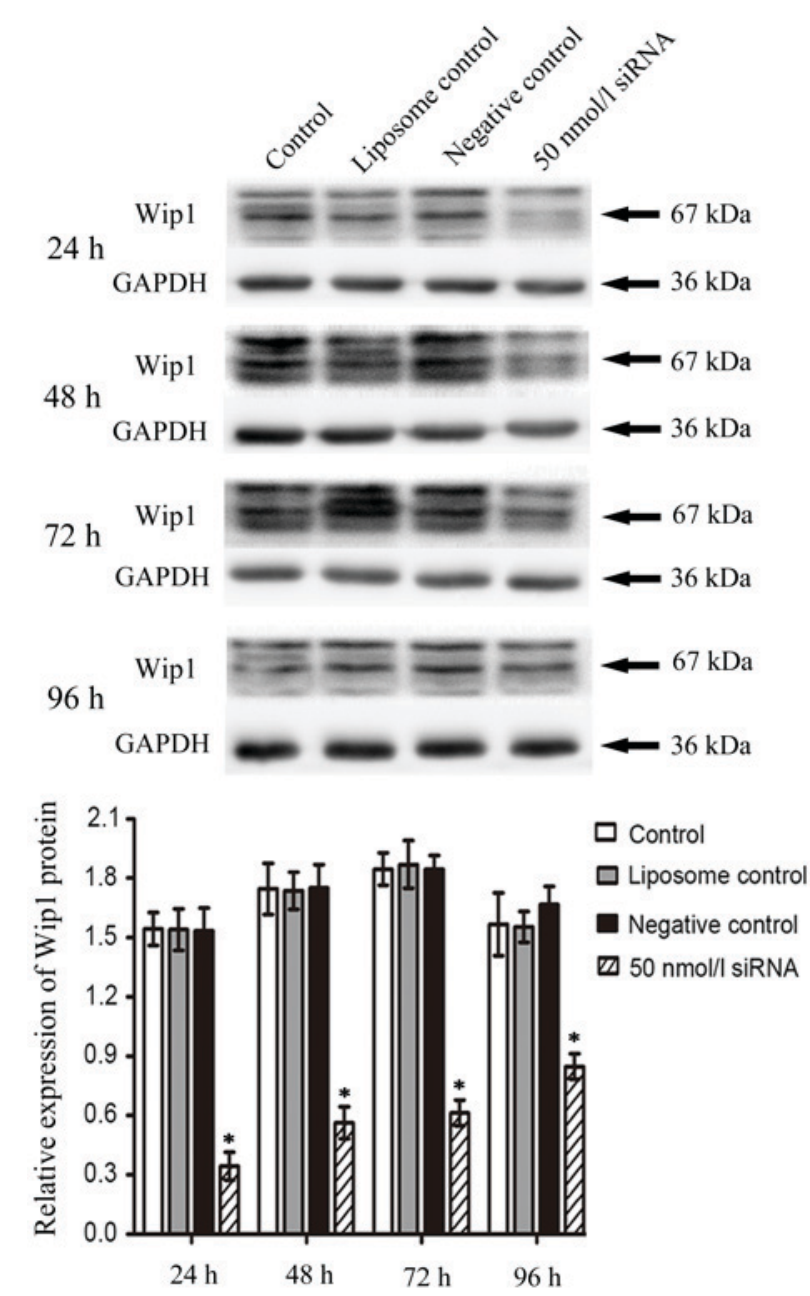

Figure 4. Influence of Wip1-811 siRNA on the protein expression of Wip1 in RKO colon cancer cells after transfection for $24-96$ h. ${ }^{*} \mathrm{P}<0.05$ vs. negative control at the same time point. Wip1, wild-type p53-induced phosphatase; siRNA, small interfering RNA.

\section{Discussion}

The p53 gene is one of the most important tumor-suppressor genes, and its mutation and functional inactivation exist in more than half of human cancers (17). The intact function of p53 is crucial to prevent cancer development. Wip1, which is encoded by protein phosphatase magnesium-dependent 1 delta, is a serine/threonine protein phosphatase belonging to the type $2 \mathrm{C}$ protein phosphatase family (7). Wip1 is activated by various stresses, and is involved in several cellular processes such as tumorigenesis and aging (18). Wipl is closely associated with p53 (8). Wip1, which is overexpressed in numerous cancers, including breast cancer (19), medulloblastoma (20), pancreatic neuroendocrine tumor (21), liver cancer (22) and stomach cancer (23), is recognized as a novel oncogene inhibiting several p53-dependent tumor-suppressor signaling pathways, including the Ataxia telangiectasia mutated-checkpoint kinase 2-p53, p38 mitogen-activated protein kinase-p53 and nuclear factor- $\kappa \mathrm{B}$ signaling pathways (19). Discher et al (14) reported that Wip1 was associated with the chemosensitivity of cancer, since downregulation of Wip1 gene expression could inhibit the self-proliferation of breast cancer stem cells and enhance the chemosensitivity of MCF-7 breast cancer cells to doxorubicin. 
Table I. IC50 of 5-FU, oxaliplatin and adriamycin in different groups.

$\mathrm{IC}_{50}(\mu \mathrm{mol} / 1$, mean \pm standard deviation $)$

\begin{tabular}{lccc}
\cline { 2 - 3 } Group & 5 -FU & Oxaliplatin & Adriamycin \\
\hline Control & $66.38 \pm 9.26$ & $45.08 \pm 4.74$ & $2.22 \pm 0.21$ \\
Liposome control & $59.95 \pm 6.58$ & $41.80 \pm 3.74$ & $2.01 \pm 0.20$ \\
Negative control & $56.88 \pm 6.08$ & $43.60 \pm 3.72$ & $2.13 \pm 0.20$ \\
Wip1-811siRNA $(50 \mathrm{nmol} / \mathrm{l})$ & $25.32 \pm 2.59^{\mathrm{a}}$ & $18.74 \pm 2.21^{\mathrm{b}}$ & $0.88 \pm 0.08^{\mathrm{c}}$ \\
\hline
\end{tabular}

${ }^{\mathrm{a}} \mathrm{P}<0.05,50 \mathrm{nmol} / 1$ siRNA vs. negative control. ${ }^{\mathrm{b}} \mathrm{P}<0.05,50 \mathrm{nmol} / \mathrm{l} \mathrm{siRNA}$ vs. negative control. ${ }^{\mathrm{c}} \mathrm{P}<0.05,50 \mathrm{nmol} / \mathrm{l}$ siRNA vs. negative control. $\mathrm{IC}_{50}$, half-maximal inhibitory concentration 5-FU, 5-fluorouracil; siRNA, small interfering RNA.
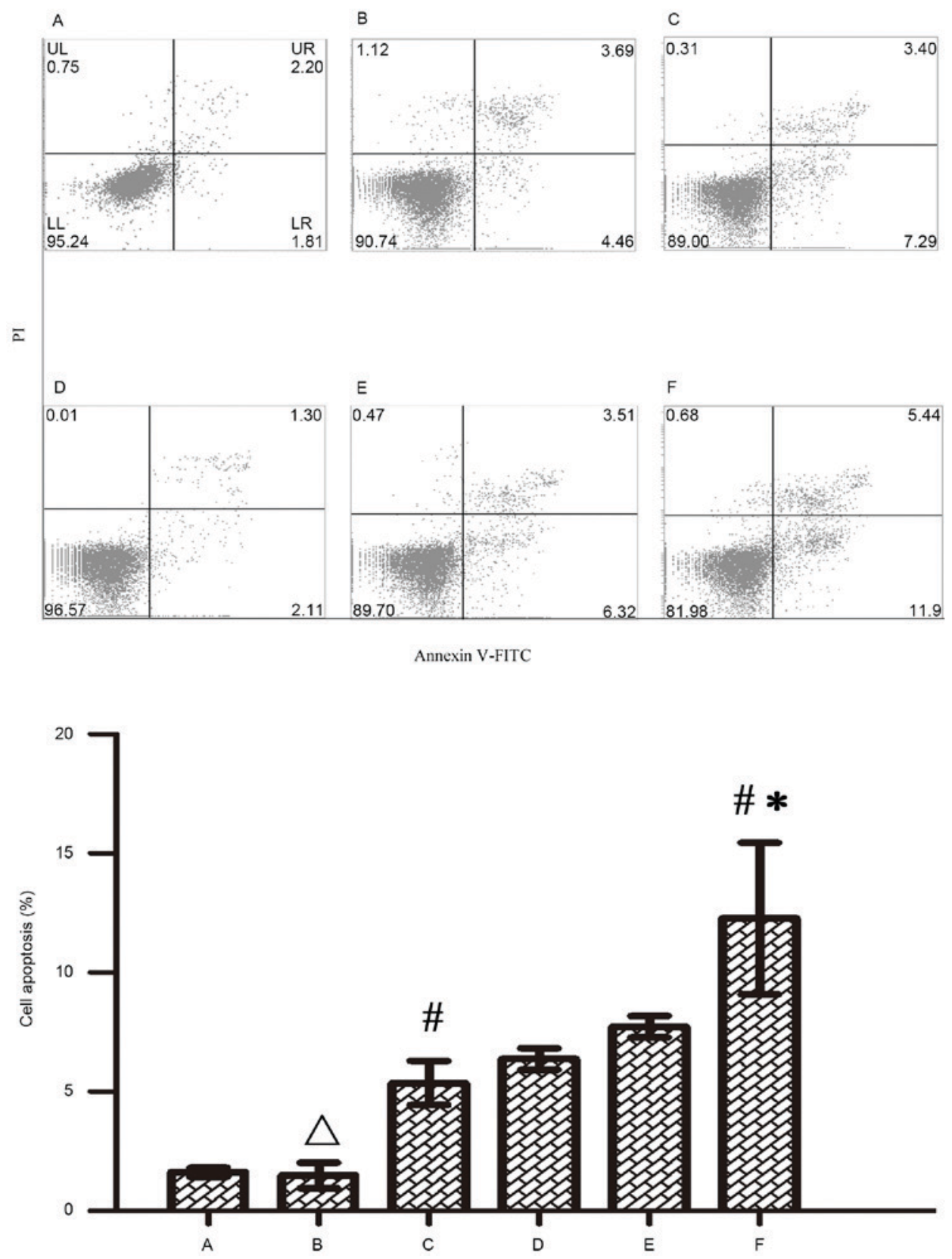

Figure 5. Influence of Wip1-811 siRNA on cell apoptosis in RKO colon cancer cells treated with 5-FU. A, Control; B, Control+5-FU; C, Negative control+5-FU; D, Wip1-811 siRNA; E, Liposome+5-FU; F, Wip1-811 siRNA+5-FU. ${ }^{4} \mathrm{P}>0.05$ vs. control; ${ }^{~} \mathrm{P}<0.05$ vs. Wip1-811 siRNA group; ${ }^{2} \mathrm{P}<0.05$ vs. negative control. Wip1, wild-type p53-induced phosphatase; siRNA, small interfering RNA; 5-FU, 5-fluorouracil; Annexin V-FITC, Annexin V-fluorescein isothiocyanate; PI, Propidium iodide; UL, upper left; UR, upper right; LL, lower left; LR, lower right. 

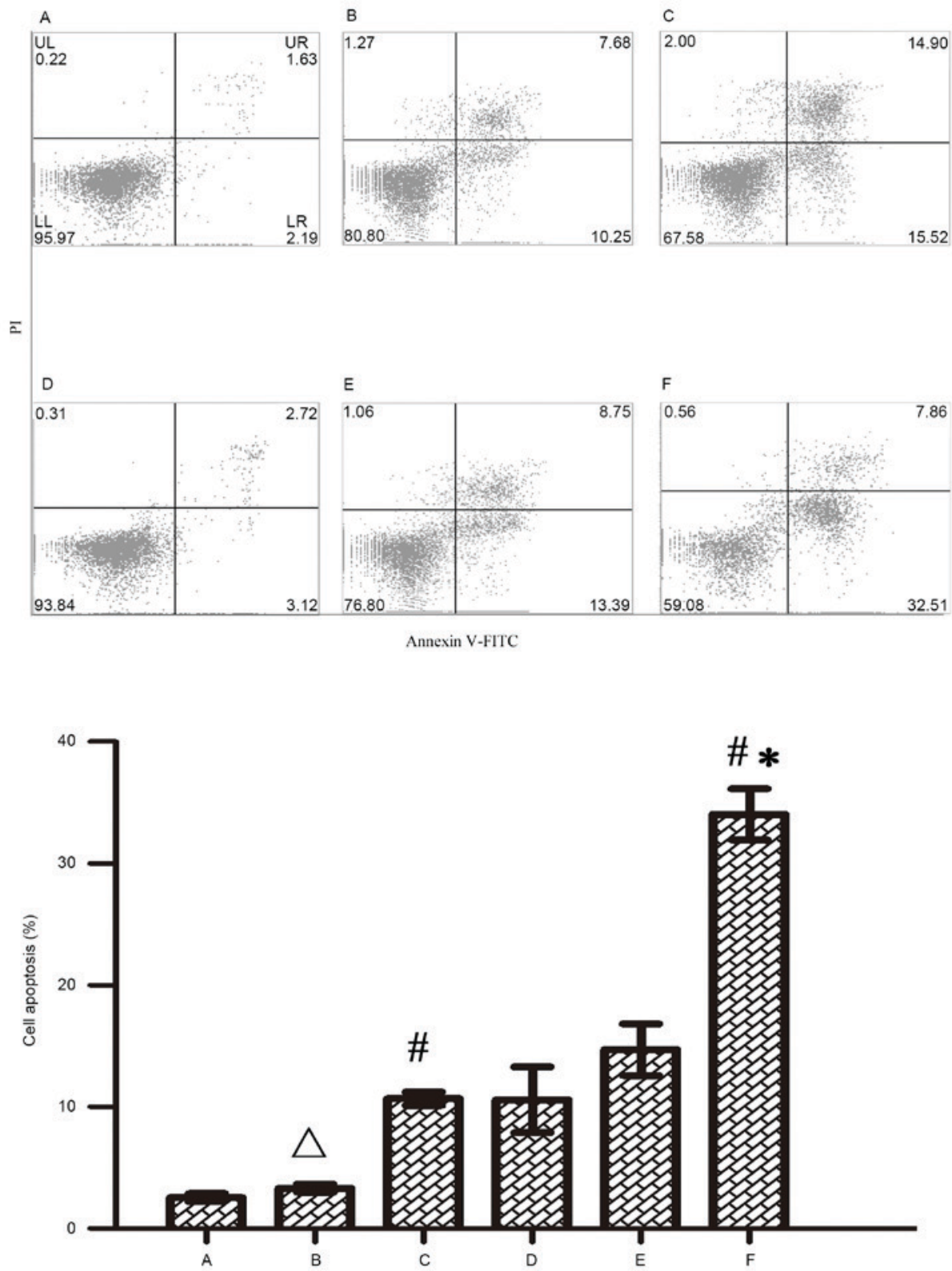

Figure 6. Influence of Wip1-811 siRNA on cell apoptosis in RKO colon cancer cells treated with oxaliplatin. A, Control; B, Control+oxaliplatin; C, Negative control+oxaliplatin; D, Wip1-811 siRNA; E, Liposome+5oxaliplatin; F, Wip1-811 siRNA+oxaliplatin. ${ }^{\triangle} \mathrm{P}>0.05$ vs. control; ${ }^{\#} \mathrm{P}<0.05$ vs. Wip1-811 siRNA group; ${ }^{*} \mathrm{P}<0.05$ vs. negative control. Wip1, wild-type $\mathrm{p} 53$-induced phosphatase; siRNA, small interfering RNA; Annexin V-FITC, Annexin V-fluorescein isothiocyanate; PI, Propidium iodide; UL, upper left; UR, upper right; LL, lower left; LR, lower right.

However, the influence of Wip1 gene on the chemosensitivity of colon cancer cells is still unclear.

In the present study, Wip1-811 siRNA targeting Wip1 mRNA was transfected into RKO colon cancer cells to investigate the influence of Wipl gene silencing on the chemosensitivity of colon cancer cells. It was observed that Wip1-811 siRNA could effectively suppress Wip1 gene expression in RKO colon cancer cells. MTS assay revealed that Wip1-811 siRNA alone had no influence on the cell proliferation of RKO colon cancer cells. However, Wip1-811 siRNA combined with 5-FU, oxaliplatin or adriamycin could kill more RKO colon cancer cells than treatment with 5-FU, oxaliplatin or adriamycin alone. By comparing the $\mathrm{IC}_{50}$ of 5-FU, oxaliplatin or adriamycin in each group, it was observed that the $\mathrm{IC}_{50}$ values of these drugs in the Wip1 siRNA group were significantly lower than those in the three control groups. This indicates that Wip1 gene silencing could enhance the chemosensitivity of RKO colon cancer cells.

Cell apoptosis and cell cycle analyses by flow cytometry revealed that Wip1-811 siRNA alone had no influence on cell proliferation, cell apoptosis or cell cycle. However, when combined with antitumor drugs, the cell viability of RKO colon cancer cells in the Wipl siRNA group was significantly lower than that in the control groups. In addition, the cell apoptosis of RKO colon cancer cells in the Wip1 siRNA group was significantly increased compared with that in the control groups. There was no significant difference on the cell cycle of RKO colon cancer cells in the Wipl siRNA group and the other groups. This indicated that Wipl siRNA enhanced the chemosensitivity of RKO colon cancer cells via augmentation of cell 
Table II. Influence of Wip1-811 siRNA on the cell cycle of RKO colon cancer cells treated with antitumor drugs.

\begin{tabular}{|c|c|c|c|c|}
\hline Treatment & siRNA & $\begin{array}{c}\mathrm{G} 0 / \mathrm{G} 1 \text { phase } \\
(\%, \text { mean } \pm \text { standard } \\
\text { deviation })\end{array}$ & $\begin{array}{c}\text { S phase } \\
(\%, \text { mean } \pm \text { standard } \\
\text { deviation })\end{array}$ & $\begin{array}{c}\mathrm{G} 2 / \mathrm{M} \text { phase } \\
(\%, \text { mean } \pm \text { standard } \\
\text { deviation })\end{array}$ \\
\hline \multicolumn{5}{|c|}{ 5-Fluorouracil $(\mu \mathrm{mol} / \mathrm{l})$} \\
\hline \multirow[t]{2}{*}{0} & Control & $50.5 \pm 7.3$ & $35.0 \pm 2.5$ & $14.6 \pm 7.0$ \\
\hline & Wip-811 siRNA & $49.9 \pm 2.4^{\mathrm{a}}$ & $33.5 \pm 4.1$ & $16.6 \pm 6.2$ \\
\hline \multirow[t]{2}{*}{5} & Control & $60.9 \pm 3.8^{\mathrm{b}}$ & $28.9 \pm 1.5$ & $10.3 \pm 5.2$ \\
\hline & Wip-811 siRNA & $64.8 \pm 4.3^{c}$ & $20.7 \pm 4.4$ & $14.4 \pm 5.5$ \\
\hline \multicolumn{5}{|c|}{ Oxaliplatin $(\mu \mathrm{mol} / \mathrm{l})$} \\
\hline \multirow[t]{2}{*}{0} & Control & $59.0 \pm 6.4$ & $28.8 \pm 5.8$ & $12.2 \pm 0.6$ \\
\hline & Wip-811 siRNA & $54.5 \pm 4.6$ & $33.8 \pm 5.3$ & $11.7 \pm 1.7^{\mathrm{a}}$ \\
\hline \multirow[t]{2}{*}{5} & Control & $60.4 \pm 3.4$ & $11.9 \pm 1.5$ & $27.7 \pm 1.9^{\mathrm{b}}$ \\
\hline & Wip-811 siRNA & $58.5 \pm 3.1$ & $12.3 \pm 2.7$ & $28.2 \pm 6.7^{c}$ \\
\hline
\end{tabular}

${ }^{a} \mathrm{P}>0.05$, non-drug plus siRNA group vs. control. ${ }^{\mathrm{b}} \mathrm{P}<0.05$, chemotherapy drug group vs. non-drug group. ${ }^{\mathrm{c}} \mathrm{P}>0.05$, chemotherapy drug plus siRNA group vs. control. Wip1, wild-type p53-induced phosphatase; siRNA, small interfering RNA.

Table III. Fluorescence intensity of adriamycin in RKO colon cancer cells following transfection with Wip1-811 siRNA.

\begin{tabular}{lc}
\hline Group & $\begin{array}{c}\text { Fluorescence intensity } \\
\text { of adriamycin }\end{array}$ \\
Control & AU, mean \pm standard deviation) \\
Liposome control & $395.23 \pm 29.85$ \\
Negative control & $425.21 \pm 18.91$ \\
Wip1-811 siRNA & $431.19 \pm 6.28^{\mathrm{a}}$ \\
COLO 320DM & $441.61 \pm 23.49^{\mathrm{b}}$ \\
colon cancer cells & $196.45 \pm 20.08$ \\
Positive control & $410.63 \pm 30.57^{\mathrm{c}}$ \\
\hline
\end{tabular}

${ }^{\mathrm{a}} \mathrm{P}>0.05$, Wip1-811 siRNA vs. negative control. ${ }^{\mathrm{b}} \mathrm{P}>0.05$, negative control vs. control. ${ }^{\mathrm{P}} \mathrm{P}<0.05$, positive control vs. COLO 320DM colon cancer cells. Wip1, wild-type p53-induced phosphatase; siRNA, small interfering RNA.

apoptosis but not alteration of the cell cycle. Nopel-Dünnebacke et al (24) reported that the downregulation of Wip1 gene expression could increase the p53 expression level and directly induce cell apoptosis. High expression levels of p53 could improve the outcome of chemotherapy for patients with colon cancer who accepted regimens based on 5-FU and oxaliplatin. Bisteau et al (25) reported that the inhibition of Wip1 gene expression could increase the accumulation of wild-type p53 protein and induce the cyclin D1 expression, which was accompanied by an increased in the percentage of cells in $\mathrm{S}$ phase. Therefore, the inhibition of Wip1 gene expression enhanced the chemosensitivity of liver cancer cells. However, the present study demonstrated that the downregulation of Wipl gene expression alone could not increase cell apoptosis or change the cell cycle of RKO colon cancer cells. Thus, the alternative mechanism of enhanced chemosensitivity in RKO colon cancer cells by Wip1 gene silencing still requires to be further investigated. Brazina et al (26) proposed that Wip1 was one of the negative feedback key factors of death-associated protein 6 (Daxx) phosphorylation. High expression of Wip1 could inhibit Daxx phosphorylation induced by DNA damage and prevent cell apoptosis from occurring, thus increasing the resistance of cells to stimulation (26). Wipl gene silencing may inhibit the self-proliferation of cancer stem cells and therefore participate in the regulation of the chemosensitivity of cancer cells (27).

The classical reversal of multidrug resistance is targeting drug efflux pumps to increase intracellular antitumor drug accumulation in cancer cells. However, in the present study, intracellular adriamycin accumulation assay by flow cytometry revealed that there was no significant difference between the Wip1-811 siRNA group and the three control groups. Therefore, it can be inferred that Wip1 gene silencing enhanced the chemosensitivity of RKO colon cancer cells not via drug efflux pumps.

In the present study, Wipl siRNA was transiently transfected into RKO colon cancer cells to successfully inhibit the gene expression of Wipl. The downregulation of Wipl gene expression could enhance the chemosensitivity of RKO colon cancer cells, which provided a new potential approach for the reversal of multidrug resistance in colon cancer. However, siRNA transient transfection has certain disadvantages such unsatisfactory inhibition of the target gene and short time effects (5). Furthermore, the results of the present study were obtained in vitro. In the future, a stable expression vector for Wip1-811 siRNA must be constructed. Furthermore, long-term, stable RNAi by Wip1-811 siRNA in vivo must also be investigated.

In conclusion, Wip1-811 siRNA could induce Wip1 gene silencing. Wip1-811 siRNA could enhance the chemosensitivity of RKO colon cancer cells via augmentation of cell apoptosis but not alteration of the cell cycle or intracellular antitumor drug accumulation in RKO colon cancer cells. 


\section{Acknowledgements}

The present study was supported by grant no. [2013]163 from the Key Laboratory of Malignant Tumor Molecular Mechanism and Translational Medicine of Guangzhou Bureau of Science and Information Technology, and grant no. KLB09001 from the Key Laboratory of Malignant Tumor Gene Regulation and Target Therapy of Guangdong Higher Education Institutes.

\section{References}

1. Wiseman M: The second world cancer research Fund/American institute for cancer research expert report: Food, nutrition, physical activity, and the prevention of cancer: A global perspective. Proc Nutr Soc 67: 253-256, 2008.

2. Douillard JY, Cunningham D, Roth AD, Navarro M, James RD, Karasek P, Jandik P, Iveson T, Carmichael J, Alakl M, et al: Irinotecan combined with fluorouracil compared with fluorouracil alone as first-line treatment for metastatic colorectal cancer: A multiple multicentre randomised trial. Lancet 355: 1041-1047, 2000 .

3. Redmond SM, Joncourt F, Buser K, Ziemiecki A, Altermatt HJ, Fey M, Margison G and Cerny T: Assessment of P-glycoprotein, glutathione-based detoxifying enzymes and O6-alkylguanine-DNA alkyltransferase as potential indicators of constitutive drug resistance in human colorectal tumors. Cancer Res 51: 2092-2097, 1991.

4. Van de Vrie W, Gheuens EE, Durante NM, De Bruijn EA, Marquet RL, Van Oosterom AT and Eggermont AM: In vitro and in vivo chemosensitizing effect of cyclosporine A on an intrinsic multidrug-resistant rat colon tumour. J Cancer Res Clin Oncol 119: 609-614, 1993.

5. Xia Z, Zhu Z, Zhang L, Royal C, Liu Z, Chen Q and Adam BL: Specific reversal of MDR1/P-gp-dependent multidrug resistance by RNA interference in colon cancer cells. Oncol Rep 20: $1433-1439,2008$

6. Damiani D, Michieli M, Michelutti A, Melli C, Cerno M and Baccarani M: D-verapamil downmodulates P170-associated resistance to doxorubicin, daunorubicin and idarubicin. Anticancer Drugs 4: 173-180, 1993.

7. Fiscella M, Zhang H, Fan S, Sakaguchi K, Shen S, Mercer WE, Vande Woude GF, O'Connor PM and Appella E: Wip1, a novel human protein phosphatase that is induced in response to ionizing radiation in a p53-dependent manner. Proc Natl Acad Sci USA 94: 6048-6053, 1997.

8. Shi Y: Serine/threonine phosphatases: Mechanism through structure. Cell 139: 468-484, 2009.

9. Donehower LA: Phosphatases reverse p53-mediated cell cycle checkpoints. Proc Natl Acad Sci USA 111: 7172-7173, 2014.

10. Lu X, Nannenga B and Donehower LA: PPM1D dephosphorylates Chk1 and p53 and abrogates cell cycle checkpoints. Genes Dev 19: 1162-1174, 2005.

11. Demidov ON, Timofeev O, Lwin HN, Kek C, Appella E and Bulavin DV: Wip1 phosphatase regulates p53-dependent apoptosis of stem cell and tumorigenesis in the mouse intestine. Cell Stem Cell 1: 180-190, 2007.
12. Li ZT, Zhang L, Gao XZ, Jiang XH and Sun LQ: Expression and significance of the Wip1 proto-oncogene in colorectal cancer. Asian Pac J Cancer Prev 14: 1975-1979, 2013.

13. Zhao M, Zhang H, Zhu G, Liang J, Chen N, Yang Y, Liang X, Cai $\mathrm{H}$ and Liu W: Association between overexpression of Wipl and prognosis of patients with non-small cell lung cancer. Oncol Lett 11: 2365-2370, 2016.

14. Discher DE, Janmey P and Wang YL: Tissue cells feel and repond to the stiffness of their substrate. Science 310: 1139-1143, 2005.

15. Livak KJ and Schmittgen TD: Analysis of relative gene expression data using real-time quantitative PCR and the 2(-Delta Delta C(T)) method. Methods 25: 402-408, 2001.

16. Li J, Xu LZ, He KL, Guo WJ, Zheng YH, Xia P and Chen Y: Reversal effects of nomegestrol acetate on multidrug resistance in adriamycin-resistant MCF7 breast cancer cell line. Breast Cancer Res 3: 253-263, 2001.

17. Chang F, Syrjänen S, Kurvinen K and Syrjänen K: The p53 tumor suppressor gene as a common cellular target in human carcinogenesis. Am J Gastroenterol 88: 174-186, 1993.

18. Lu G and Wang Y: Functional diversity of mammalian type $2 \mathrm{C}$ protein phosphatase isoforms: New tales from an old family. Clin Exp Pharmacol Physiol 35: 107-112, 2008.

19. Yu E, Ahn YS, Jang SJ, Kim MJ, Yoon HS, Gong G and Choi J: Overexpression of the Wip1 gene abrogates the p38 MAPK/p53/Wip1 pathway and silences p16 expression in human breast cancers. Breast Cancer Res Treat 101: 269-278, 2007.

20. Baxter EW and Milner J: p53 regulates LIF expression in human medulloblastoma cells. J Neurooncol 97: 373-382, 2010.

21. Hu W, Feng Z, Modica I, Klimstra DS, Song L, Allen PJ, Brennan MF, Levine AJ and Tang LH: Gene Amplifications in well-differentiated pancreatic neuroendocrine tumors inactivate the P53 pathway. Genes Cancer 1: 360-368, 2010.

22. Zhu YH and Bulavin DV: Wip1-dependent signaling pathways in health and diseases. Prog Mol Biol Transl Sci 106: 307-325, 2012.

23. Fuku T, Semba S, Yutori H and Yokozaki H: Increased wild-type p53-induced phosphatase 1 (Wip1 or PPM1D) expression correlated with downregulation of checkpoint kinase 2 in human gastric carcinoma. Pathol Int 57: 566-571, 2007.

24. Nöpel-Dünnebacke S, Schulmann K, Reinacher-Schick A, Porschen R, Schmiegel W, Tannapfel A and Graeven U: Prognostic value of microsatellite instability and p53 expression in metastatic colorectal cancer treated with oxaliplatin and fluoropyrimidine-based chemotherapy. Z Gastroenterol 52: 1394-1401, 2014.

25. Bisteau X, Caldez MJ and Kaldis P: The complex relationship between liver cancer and the cell cycle: A story of multiple regulations. Cancers (Basel) 6: 79-111, 2014.

26. Brazina J, Svadlenka J, Macurek L, Andera L, Hodny Z, Bartek J and Hanzlikova H: DNA damage-induced regulatoryinterplay between DAXX, p53, ATM kinase and Wip1 phosphatase. Cell Cycle 14: 375-387, 2015.

27. Zhang X, Wan G, Mlotshwa S, Vance V, Berger FG, Chen H and $\mathrm{Lu}$ X: Oncogenic Wip1 phosphatase is inhibited by miR-16 in the DNA damage signaling pathway. Cancer Res 70: 7176-7186, 2010. 